\title{
HEGEL ON RIGHT AS ACTUALIZED WILL
}

\author{
DONALD J. MALETZ \\ University of Oklahoma
}

$\mathbf{H}$ foundation of right or justice, which is to be found in the psychology of the free will. Second, Hegel argues that willing strives to do or to achieve something; will particularly seeks an outcome in which its own inner freedom is given practical external expression or is made actual, and so right is not just willing but also result, will's actualization. The $P R$ is therefore as much an investigation of the possible ways in which the free willing subject could be accommodated in practical institutions as it is an exploration of the psychology of willing on its own terms. These two themes define the structure of the $P R$ but, as one would expect from Hegel, they imply a third: namely, the attempt to understand them together as complementary parts of a whole, so that both the origin and the result are seen precisely as the origin and the result of each other, and thus the phenomenon is understood for what it is as a whole. ${ }^{1}$

Hegel believed the $P R$ represented a fundamental rethinking of the problem of right or justice. ${ }^{2}$ It summarized a lifetime of his own thought ${ }^{3}$ and responded as well to a particular crisis of his own time, in which the possibility of any successful philosophical treatment of justice or right was denied. 4 One part of the crisis pitted the defenders of freedom, subjectivity, and individuality against the "state," the former tending to seek liberation from constraints in a critical outlook based on the liberated mind, the latter coming to disdain the intellect and regard philosophy as something to be, at best, tolerated "comme les bordelles." The crisis took many forms, some purely local, but it rested on a fundamental problem, as Hegel well understood: Granted that there is in the modern world somehow an enhanced awareness of the capacity,

AUTHOR'S NOTE: An earlier version of this article was presented at the 1986 meeting of the Southwestern Political Science Association.

POLITICAL THEORY, Vol. 17 No. 1, February 1989 33-50

๑ 1989 Sage Publications, Inc. 
even the duty, for an individual to question, criticize, and investigate, according to the dictates of his own mind, then what will be the outcome of this heightened critical subjectivity? Does it lead to a subjectivism that is ultimately only critical and in the last analysis merely deconstructive, to use a contemporary term? Or is it finally also constructive, capable of actualization in public institutions that are within our reach and that do not merely tolerate the free subject but are the very embodiment of the free subject's deepest needs and aims, including the need for society and state?

Hegel's two themes address this issue directly. By beginning with the freely willing subject, Hegel embraces as the basis of right the principle of active, critical, self-liberating, psychological autonomy, the source of much that is revolutionary in modernism; Hegel stands firmly on this avowedly modern principle and deepens it. On the other hand, he insists that the priority of will cannot in the last analysis mean solely a priority of criticism and dissent. Willing, he insists, necessarily strives toward something positive, in the sense of a practicable way of life in an existing socicty and state, and the nature, the path and the outcome of that orientation toward a goal is the theme most needing clarification and deepening. How, in short, does this activism of free subjectivity complete or fulfill itself?

The $P R$ opens with an "Introduction" providing a highly abstract account of the will. The lengthy main text of the $P R$, seemingly by contrast, considers topics familiar to us as law, morality, the family, civil society, the state and finally history (or, in other words, the themes of legal, moral, social and political philosophy, with the important addition of the philosophy of history); Hegel's own terminology provides three major categories, called "abstract right," "morality" and "the ethical world." In the section I have just called the "main text" of the $P R$, the theme of will seems to disappear at least from the surface of the argument, while the discussion takes up what appear to be rather ordinary social and political institutions that Hegel then presents as the actualization of right. He defends what seem to be some of the basic structures of the "conventional" world of the modern west European society and state as it was emerging in the postrevolutionary nineteenth century. As a result, it might be thought that Hegel surreptitiously abandons the thesis of the primacy of the will and defends the practical world of his day in practical terms, taking the side of the "state," as it were, against the "will." However, as I intend to show, this impression is incorrect. The primacy of the will remains the foundation for the 
entire structure of the $P R$, and Hegel does not discard his argument that all right comes from will, even if he proposes to instruct us more deeply about the matter of the will's actualization. ${ }^{7}$ The following remarks are meant to examine the willed character of right as Hegel understands it.

In order to grasp Hegel's aim, it is first necessary to have an at least preliminary understanding of what he means by will, as he outlines it in the extraordinarily terse introduction to the $P R$. An aspect of Geist, the mind or spirit, the will is identical with the freedom of the mind or spirit taken in two related senses. It is, first, that absence of complete determination by natural forces which allows or compels the mind or spirit to operate by itself and for itself, subject to its own norms. ${ }^{8}$ Second, it is an inherent directedness that belongs to mind or spirit, and that makes its freedom more than merely blank indeterminacy. This directedness is revealed in the striving to confront what is external and open it up by thought, to insist on pressing further until all things are accessible to thought, and finally to so shape the practical conditions of life that they constitute an appropriate home for a life structured in accordance with the mind or spirit's own self-generated imperatives. 9 Will underlies both theory and practice, both the quest to understand the things that come before us and the drive to set our own standards into effective existence, rather than simply obeying whatever powerful forces attempt to shape our way of life. ${ }^{10}$ In this sense, will cannot be called a distinct faculty alongside other faculties, because it is an activism that affects all operations of the mind or spirit; and it is not a focused wanting of this or that, but a larger drive to activate the mind or spirit fully and to shape all of the conditions of practical life accordingly.

Hegel wants to call this original mental or spiritual activism the basis of right. At first glance it might seem, to the contrary, that will, as described, is the root of wrong, and that the task in practice and in theory is to subdue this will by inducing it to listen to reason. Will as Hegel presents it appears to be akin to that which Rousseau blamed for ripping mankind out of the natural order. ${ }^{11}$ It seems to be the source of rebellion against the constraints of law, morality, or society, insofar as rebellion claims to be based on some impulse of the critical mind. But Hegel insists that exactly the will is to be taken as the source of right. Although criticism and negation prove to be essential acts of the free will and essential steps toward the achievement of freedom, they are not, Hegel argues, purely negative, properly understood; they are preparatory to the establishment of laws, norms, and institutions that are shaped by the drive toward freedom and that offer an accommodation 
to that drive so that it exists effectively in the world of nature and history. ${ }^{12}$ The story is one in which an original freedom that is premoral, prelegal, and presocial eventuates in a long historical process of development finally establishing the institutions of the modern state, which - contrary to the appearance they offer at first glance - are built exactly from the basis of that original freedom and furthermore are only susceptible of justification to the extent that that basis can be made clear.

While the $P R$ begins by looking, however cautiously, into the autonomous depths of the mind or spirit and its "will," Hegel's discussion of achieved right seems to follow the line suggested by the provocative sentence from his "Preface," to the effect that "the truth about right, ethics and the state is as old as its public recognition and formulation in the law of the land, in the morality of everyday life, and in religion." ${ }^{13} \mathrm{Hegel}$ indeed seems to propose nothing that is revolutionary and certainly avoids any utopianism, any attempt to teach the state how it "ought" to be in any extreme sense. It is, of course, true that, while the institutions he presents as right may be somewhat familiar, the explanations for them are hardly so; and it is true that Hegel by no means defends everything that is established. Nevertheless, we find in the $P R$ a distinct, if critical, respect for what has taken firm root in the public mind and in public practice. But that respect is guided by certain definite critical principles, allowing for a distinction between what is merely inherited and what is justifiably established, or in need of establishment. Hegel's purpose is to show how the notion of will constitutes the basis for tying familiar structures together into a philosophically defensible system of right, where right will be seen to have a "willed"character; his concern with the objective actualization of will in practical public institutions modifies but does not suppress the autonomy of will. To the contrary, will, as the radical autonomy of mind or spirit, remains a highly potent component of achieved right. To examine how this is so, let me consider, first, the formal structure of right, where Hegel's method of linking each aspect of right to the rext shows something important about the experience of right and the knowledge of right. Second, I examine the critique of arbitrariness or willfulness (Willkür) with which Hegel poses a criticism of a certain defective understanding of freedom by arguing from the basis of the will correctly understood. Finally, I treat Hegel's sphere of "absolute right," which is "world history." Here the will reaches a sort of culmination in which it does, in a sense, attain a kind of completeness. 
The formal structure of the account of right is meant by Hegel to present the form of willing and the form of its movement toward actualization. ${ }^{14}$ Each major division of the account of right commences with a brief statement explaining its relation to the inner psychology of will as it strives toward achievement; and then Hegel examines the expression of the psychological impulse in practical institutions. The realm of achieved right, established in institutions, tells us something about the effective core of the mind or spirit, because the achieved right is seen as its result. ${ }^{15}$ The formal structure of the $P R$ taken as a whole embodies Hegel's account of the beginning and the end in matters of right, the path from one to the other, and the course of experience and thought that most reveals both the basis and the outcome of right. The essential problem is to find the order leading not to some novelty but to the rational core of what we already know naively. ${ }^{16}$ No one is without experience of law, moral norms, the family and other forms of society. But what we "know" in this way from direct experience is ordinarily highly confused, lacking in a center, filled with contradictory or at least discordant elements. The task of an account of right is to deepen and clarify this experience and to link it with its psychological foundation.

As we see immediately from the form into which Hegel puts this quest, the clarification of right does not follow the path of individual chronological experience nor of collective historical development. Individual experience of right (and possibly even the general human experience in a historical sense) presumably begins with the family, in which the first sentiments about duty are nurtured affectively. However, Hegel commences not with the family as such but with a comparatively more recent development, the sense of abstract right based on concepts of personhood. ${ }^{17}$ Abstract right is an elementary external manifestation of a step taken by will in its search for actualization of its own freedom. The will's internal process is, first, abstraction from content and construction of a norm that is explicitly not dependent on external factors; second, the overcoming of the passive abstractness of this detached norm, by trying to make it a guide for a more concrete engagement with the opportunities offered by the world (morality, action guided by mind or spirit); third, recognition that these two alternatives still remain too abstract and development of a more conscious, complete appropriation of the human experience found in society and history (ethical life), as shaped, however, by the prior stages of willing. The form of Hegel's argument is, in short, not just an external structure imposed on the material to give it scholarly coherence. It 
purports rather to capture the distinctive manner in which will itself develops, once that development is brought explicitly to light. The method is called by Hegel the philosophical approach to right and as such it differs from the course of historical or biographical experience. ${ }^{18}$

If we examine the order, we see at once how thoroughly it differs from the historical order. Historically speaking, the family, civil society, and elements of "the state" precede the emergence of a sense of abstract right or of the morality of individual free conscience. But the historical appearance is deceptive, Hegel suggests, because the abstract concept of personhood and then of personal rights may in a certain way be a necessary presupposition of these social forms - a presupposition in the sense of a necessary element for the full development of the social realm in a complete and justifiable form. ${ }^{19}$ Thus, society in a historical sense predates the abstract sense of right; in another sense, society without the notion of abstract right is an unjust society, a defective form of society because without recognition of an important aspect of will. The formal arrangement of Hegel's account is meant to put the elements of legal, moral, social, and political experience into the order in which they conform to the internal development of will and in which the fully reflective will can, step by step, appropriate the necessary elements of actual right.

Furthermore, the form of Hegel's argument provides an account of the movement of thought and of experience from one aspect of right to the next. The achieved institutions of right are ordered in the way in which Hegel's psychologically grounded understanding reinterprets them, bringing to light their normally hidden psychological basis. The psychological legitimacy thereby established makes familiar institutions no longer seem to be impositions of an alien law from outside but to be grounded in a psychological need. In this way, every institution of right is dissolved, as it were, from an objective reality simply confronting us as authoritative into a product of will and its quest for self-actualization. Practices and institutions may give the appearance of being simply custom, tradition, or inherited law; yet as the willed basis is brought forward into view they are quite systematically subjectivized. ${ }^{20} \mathrm{~A}$ basis is thereby established for distinguishing what can really claim the authority of right from that which is merely historical accretion or positive injustice. As thought moves from an abstract sense of right, to mind or spirit brought to bear on action, to an appropriation of the existing forms of social life, it does so by deconstructing and reconstructing in a way that has both a theoretical and a practical component. 
Theoretically, the goal is to observe in law, moral norms, and social practices the presence and activity of free will. Practically, the aim is to reconstruct these spheres in accordance with an enhanced selfknowledge, so that an intelligent choice can be made as to what is essential and inessential in them.

Third, the formal character of the argument explicitly puts the elements of right into a relationship to each other that conforms to an inner psychological dialectic belonging to the will. Willing proceeds by abstracting from and then returning to the world in a way that knowingly shapes a certain relationship with it; but will then inevitably criticizes its achievement and tries to improve upon it by striving toward a larger framework of self-actualization. This process is dialectical, that is to say, it develops like a certain sort of conversation, in which a position is advanced and explored, its faults are discovered and made explicit, and then it is replaced by another position which includes whatever remains solid from the first point but puts the matter in a higher or more complete framework. The movement of thought and experience, of the free subject, from abstract right through morality to the ethicized world of society is explicitly given this character; this is the positive dialectic of will, which Hegel distinguishes from the negative dialectic of thought alone. ${ }^{21}$

The dialectic of will, to be sure, is in part a process of criticism and negation. But willing is also, by its very nature, a striving for positive result, be it choice leading to action or the knowing appropriation of the legitimacy of an existing practice or institution as offering a hitherto unnoticed aspect of psychological freedom once reinterpreted or reconstructed. Using the positive dialectic of will as a guide, Hegel restructures the spheres of right into an order which is precisely not that by which they first appear to us. This new order reveals the character and source of the abstract sense of right (i.e., the legal sense of personhood and of rights attaching to this status, along with the attempt to arrange human affairs according to this point of view, as for example in Roman law). Second, it exposes the defect of this purely abstract right however well-developed and searches for a way to bring the sense of personhood into a more active engagement with the shaping of purpose (i.e., the sense of morality, conscience, and the good). Finally, after bringing to light the extremism to which subjective moralism leads, it proceeds to a deeper insight into the psychological legitimacy inherent in existing social forms, even ancient ones, such as the family and then the more modern "civil society" and "state." These social and political 
institutions come to be seen in a new light; they are to be viewed as the result of a psychological process that is constantly in motion and for which any particular achievement is somewhat provisional. Ultimately, that psychological process is more the center of right than any particular historical actualization, and each actualization is but one possibility, never an absolutely necessary outcome. What is necessary, and belongs to the very nature of free will, is the constant quest for an actualization. In Hegel's ordering of the topics, he uncovers the hidden form showing how, in our relation to law, morality, and the ethical world of society, there is a psychology at work which moves dialectically from the abstract to the more concrete, seeking ever more effective actualization. Hegel's formal structure shows something about the requirement we must impose on any practice or institution pretending to be a part of right or justice. It must be amenable to, an instrument of, the struggle of willing to achieve adequate self-expression. Simultaneously, the argument shows us something about willing, namely that it develops itself through these stages that Hegel calls abstract right, morality, and the ethical world of society. ${ }^{22}$

To turn to the second of my themes: The effective presence of will in right, as found in the formal elements of willing, is obscured in the $P R$ by another aspect of Hegel's argument, the critique of willfulness or arbitrariness (Willkür). Throughout the $P R$, Hegel endorses what we would call a recognizably free society, but he does so while undertaking a simultaneous criticism of willfulness or arbitrariness. This complexity has caused difficulty in understanding his exact orientation. That Hegel leaves significant room for what is conventionally understood by individual freedom should be obvious. In each of the major sections of his argument, he suggests that the just society finds room for individual free choice precisely as a manifestation of right, not merely as a matter where justice can be blandly indifferent to what individuals do. Thus the rights attached to the legal status of personhood lead to a significant degree of autonomy in the use of possessions and in contracting. ${ }^{23}$ Likewise, within the moral sphere there is a necessary scope for personal choice in the formation of purposes, intentions, and conscience. ${ }^{24}$ Finally, the realm of ethical society specifically provides for the free individualism that Hegel calls distinctively modern. In the modern age, we find the "development of particularity," the individualism which "appeared in the ancient world as an invasion of ethical corruption and as the ultimate cause of that world's downfall." Civil society as Hegel 
understands that term does and must offer room for the free exercise and satisfaction of individual "needs, accidental caprices, and subjective desires."25

Nevertheless, after due recognition of these points, one cannot but be struck by the constant Hegelian emphasis on the vital importance of limiting “Willkür," willfulness or arbitrariness. If each sphere of right provides scope for free will as usually understood, it is in a larger sense true that in each sphere of right Hegel shows how structures of law, morality, and society rightly confine the willfulness of emancipated individualism. Willfulness, the view that "one may do whatever one wants," is "the idea which people most commonly have of freedom," as Hegel stresses early in the $P R$; and he returns to criticism of this defective view repeatedly. ${ }^{26}$ Though a common view, it betrays, Hegel says, a lack of comprehension of the truly free will and hence of right. Willfulness means living according to one's arbitrary preferences, impulses, and whims; it is akin to freedom because it is a way of giving oneself one's own directives. But willfulness has this defect: The willful person does not shape his impulses into a coherent, ordered whole, within which the choices made achieve unity, and the willful person does not achieve a "universality" of willing but remains dominated by the purely private and accidental. ${ }^{27}$ The critique suggests the manner in which will is superior to willfulness. Will aims for a mode of life that orders and arranges impulses into a coherent unity and that brings the universally human aspect to a certain priority over the merely particular. The truly free life is based on an individuation of the universally human, which requires subordinating and controlling the merely idiosyncratic to the point where it plays a secondary rather than a determinative role. ${ }^{28}$ Reflecting this argument is the priority that Hegel gives to education, laws, norms, and authoritative institutions over the opportunities for purely private satisfactions. The same themes that lead to the self-critique of willfulness as final outcome of will's striving for selfrealization lead also to the critique of mere individualism in the name of general institutions designed to educate inclination toward a more universal, public-spirited and coherent form of freedom. ${ }^{29}$

This point does not mean that Hegel subordinates liberty to authority, as if Willkür had to be countered by an external discipline for its own good, so to speak. Hegel rather argues that the constraints that can claim a higher right than willfulness are those produced by free will and justifiable in terms of this source. Will is psychologically superior to willfulness, as it is will that forces a self-criticism of the initial grasp of 
freedom as arbitrariness, doing whatever one pleases. Will compels the critical self-examination of Willkür, showing its disorder and the dependence that it engenders on whatever internal and external stimuli happen to present themselves. In Hegel's view, interpretation of the meaning and practice of freedom as arbitrariness is one-sided; it is in the last analysis impossible to prevent the mind or spirit from seeing the insufficiency of a view of freedom as the power to indulge any conceivable whim. This is not to say that Hegel denies the attractiveness of that view at a certain stage of development; rather he denies only its sufficiency. At a certain point, the limitations of arbitrary selfindulgence cannot but become evident, and as a consequence the psychological process of development renders unavoidable the quest for internal and external forms by which one can ascend to psychological coherence and to a mode of life that is more representatively human. ${ }^{30}$

In the preceding section of this argument, the role of will appeared in the critical dissolving power of mind or spirit, which proceeded through every instance of right demanding that it open itself to the testing of the mind or spirit. At the present point, on the other hand, will shows itself in the demand to ascend beyond arbitrary willfulness to that which orders the fluctuating life of impulse. The role of will properly understood leads, Hegel thinks, to a society in which laws, moral norms, organized social forms, and eventually "the state" predominate, not against the will but as its necessary expression. ${ }^{31}$ These institutions, at least in principle, are not restrictions of freedom but methods for the education of arbitrariness toward a higher level. They are in any event rather loose institutions, which by design offer significant scope for the critical, dissolving force of will and numerous opportunities for its expression. If will is psychologically superior to willfulness in the achievement of unity and coherence within the acting subject, and in giving a more universally human form to the subject, then a necessary objective expression of that psychological superiority is the set of institutions culminating in the state rightly understood. In this sense, the willed character of right is maintained by Hegel precisely in arguing the priority of publicly established institutions over immature forms for the expression of freedom. ${ }^{32}$

These remarks may introduce the third element in this account of the willed character of right, which concerns the thesis about "world history" by means of which Hegel concludes his doctrine of right. The 
preceding discussion has considered two manifestations of will. The first is the subjective side, the critical, dialectical striving that forces scrutiny of all things that it meets and that strives for ever more complete opportunities for its own self-actualization. The subjective will seems in part an adversary of all given authority, insisting on its need to establish its own criteria as supreme. The second manifestation is the objective side of will, embodied finally in the institutions of the Rechtstaat, claiming a superior authority over against Willkür. These two sides of will are certain to conflict; their conflict contains the seeds of the conflict between thought and the state, the desire to be free and the demand for an effective public order, the essentially human liberating impulses of the free mind or spirit and the equally essential human need for common institutions that unify, educate and elevate men to the level of citizens. Not only will there be conflict; more important, neither side seems able to achieve a culmination or completion as long as the two work separately. Their struggle obstructs the possibility of the achieved harmony and completion that Hegel had promised from the outset of the work.

A consideration of this kind moves the PR toward the "world history" thesis. At first glance, the doctrine of world history as "absolute right" may seem a concession to the priority of subjective spirit, in the following way. Hegel here admits that there is a significant sense in which mind or spirit moves beyond the Rechtstaat to a criticism of it. The achieved Rechtstaat is not the last word on right. The subjective will imposes the same critical questioning against the authority of any established instance of the Rechtstaat that it turns against each subordinate level of right. Every achieved state is necessarily transient; even when well-designed, it will be exposed to all of the vicissitudes of international affairs, which mean growth and development, but also war and decay. No instance of the state is flawless or eternal. But as this condition becomes clear, then there will arise the question: What is beyond the state? What is the whole to which the state belongs, and is that whole something that supersedes the state as Wille supersedes Willkür? As may be perceived, there is (as always in matters involving the will) both a subjective and an objective aspect at work: subjective, in the quest for a satisfaction greater than that provided by the instance of the Rechtstaat one might inhabit, objective in the quest for an actualization, in practical terms, of a still higher degree of freedom.

Now this questioning may lead to what Hegel seems to have thought the most profound criticism of the state, or of any achieved instance of 
right. The quest of will for self-actualization can turn, and has turned, into a systematic criticism of mundane life on the basis of an aspiration toward a superhuman perfection, a state of perfect and transcendent justice. This ambition leads to a depreciation of the mundane state in favor of an unworldly ideal ${ }^{33}$ and to a systematic division between an ideal world and the world of mundane states. Yet this idealism, and the very possibility of such a division between the mundane world and the world of mind or spirit, rests on the opinion that the satisfaction of will can be achieved in some form that frees us entirely from mundane reality and its limitations. This opinion is the subjective will's deepest method for subjecting all worldly things, including the Rechtstaat, to its exacting criticism. However, the opinion on which this criticism rests is itself in need of examination, on the grounds of the right found in the objective world. In my opinion, Hegel's argument about world history aims principally at this goal of criticizing the utopian mind. It does not seek to suppress the inquiry into a form of right beyond the achieved Rechtstaat because there is such a right; it seeks rather to offer an interpretation of this higher right that supplants the possibility of utopian idealism and that overcomes the capacity of will to pursue an uncompromising division between the aims of the mind or spirit and the possibilities available in actual practice.

Hegel's explicit teaching is that the world of history is "absolute right," the final court of judgment in matters of right. ${ }^{34}$ This teaching means there is no right higher than the forces of history, there is no supermundane world of right, be it a heaven or an intellectual ideal, from which one can look down upon the practical affairs of men and states and rightly apply the standards of a perfection that is not of this world. The full compass of willing is within, and necessarily belongs within, the mundane world; it necessarily reforms and improves that world, in the long run, but is not capable of transcending it. This is the meaning of "world history" as the ultimate manifestation of right. What does not belong to this historical realm cannot be part of right. ${ }^{35}$ We can say that Hegel's point acknowledges the striving of will beyond the achieved Rechtstaat because he shows how the quest for freedom ascends toward something more comprehensive than the state; it must therefore eventually seek an insight into world history from which one can assess the transience of individual states, see each as a composite of natural and human forces, grasp that growth and decay are inevitable, put each state into a framework showing how it contributes something to an overall story of progress and development, recognize the pattern of 
historical movement and progress that in one way or another affects the opportunities available, and so forth. ${ }^{36}$ Seeing the historical framework is a way to put the individual case into a larger perspective, to see it as a member of the genus, to see the "idea" of which individual states are only more or less imperfect instantiations.

On the other hand, if this insight is akin to the way in which subjective will puts every achieved instance of right into context and thereby learns to see it as only one possible actualization, there is another sense in which insight into the meaning of history puts the category of the objective over that of the subjective. History is the accumulated outcome of human choices and decisions; it is the record of the will's achievements, the exoteric expression through which we discern what is substantive in the will. Its lessons confront our hopes with the higher right of objective developments, which are in turn to be seen not as mindless facts but as the external manifestations of mind or spirit. This lesson furnishes grounds for criticism of utopianism, whether intellectual or theological. It is a lesson, however, that is only learnable by means of the key enabling one to distinguish the accidental and ephemeral from the essential in history. That key lies in the concept of will. History is the telos of the will, the outcome of will, its full self-display or selfactualization. As such, it is the whole that supersedes the distinction between subjective willing and objective result, because it is the basis within which both emerge and toward which each moves to achieve completion.

History, it should be said, must not be understood as the termination of willing but as the forum in which the willed character of right can be recognized as such. ${ }^{37}$ Nothing in the historical concept invites the end of willing, it only invites the end of that kind of willing that strives beyond history in the direction of an idealism destructive to the "state" properly conceived. ${ }^{38} \mathrm{Hegel}$ in this way suggests what might be called "historical idealism"- the insight into the effective actualization of the mind or spirit's willing within history and into the satisfying or complete character of this actualization, with the recognition that this is the only possible framework for action. Historical idealism shows that the critique of achieved right does not end with the establishment of the Rechtstaat, but proceeds to a view of the whole panorama of human action. Yet it does so with the aim of showing that "world history" and only "world history" can be the outcome of the will. There is no other place for expressing the will toward freedom than in the "state" situated within "history." The doctrine of history as absolute right is a 
transcendence of the "state" but a peculiarly "realistic" transcendence, offering a position from which to undertake a historicizing critique of idealism ${ }^{39}$; historical idealism aims to overcome the gulf that separated "idea" from "history."

The section on world history should be regarded as an answer to the questions: How are the two aspects of will brought together and what is the highest actualization of the will? Hegel's reply to both questions is: history, understood both in a positive and a negative way. The positive meaning is that, in the story of human affairs, we do see the actualization of the free will in progressively more complete ways. Above all, there is the early progress toward institutions of freedom in classical antiquity, the fracturing of classical civilization under political, philosophical, and religious onslaughts, and then the possibility of a regained wholeness in the post-revolutionary age of the nineteenth century European state. ${ }^{40}$ The negative meaning is that, in the story of human affairs, we see nothing but the free will acting within mundane circumstances. In particular, we do not encounter any utterly alien law-natural or divine-giving us an order to which we are compelled to conform regardless of consent, will, or insight.

Hegel considers it vital to the project of the $P R$ to suggest this last point, because it indicates how thought can be brought to give up its dream of teaching the state what it ought to be and to learn a new realism. Hegel seems to have thought that if he could account in purely human terms for both the origin (subjective will) and result (the achieved right of law, morality, society, and state) of all concern for right, then we could exclude the possibility that such concern somehow drives us to seek another world beyond this one. As we explore the depths of psychology and its aims, and then find in the actualization of those aims a certain decisive kind of human completion or fulfillment (albeit mundane), then there is no longer a need to believe that our concern for right forces us to pursue unattainable perfections.

This line of thought recapitulates one of Hegel's earliest concerns, deriving from the time when he believed that a certain kind of human wholeness prevailed in classical antiquity, only to be undermined by the development of a deeper sense of individuality, the influence of biblical religion, and the growth of the critical intellect. Despite important ways in which he modified his earlier longing for Hellas, as it has been called, ${ }^{41}$ the vision of a new wholeness as perhaps once more available remained with him and defined the ultimate goal to be pursued with a modern doctrine of right. If he could provide a coherent account of the 
origin and result of right, then he would have demystified and grounded law, morality, society, and state. It is the longing for a better world, and the sense of hearing an authoritative command pointing toward that world, that arouses excessive hopes, prompts men to divide themselves in two, and creates a radical unsettling of life that can, it is true, be productive, but that in the long run is an obstacle to be overcome. The diremption of man is a part of the struggle for right, in that it arises from the will, which breaks apart what is given and strives for the better. But a permanent dividedness would be chaos. The completion of will must be a new achieved wholeness, not in the form of a return to naiveté, which is impossible, but in the form of a consciously ordered and harmonized union of subjective and objective will in which neither in principle defeated or permanently disrupted the other. If it can be shown that subjective will acknowledges the achieved framework of right in the established institutions of the modern state; and if it can be shown that these institutions derive from willing, are compatible with the continued exercise of the will and have as their end the provision of a framework for a free life; then the result will be a reconciliation of willing and what has been willed, and a lowering of heaven back down to a reformed, mundane world. With precisely this thought, Hegel concludes the Philosophy of Right. ${ }^{42}$

\section{NOTES}

1. G.W.F. Hegel, Grundlinien der Philosophie des Rechts, Vol. 7, in Sämtliche Werke, 20 Vols., ed. Hermann Glockner (Stuttgart: Frommanns Verlag, 1928), paragraphs 1-4. References are to this edition. I have also made extensive use of G.W.F. Hegel, Vorlesungen Über Rechtsphilosophie 1818-1831, 4 Vols., ed. Karl-Heinz Ilting (StuttgartBad Canstatt: Frommann-Holzboog, 1973-1974). Translations are based on Hegel: Philosophy of Right, trans. by T. M. Knox (Oxford: Clarendon Press, 1942). Throughout, references to the Philosophy of Right will be given as $P R$ (paragraph numbers will be indicated by $\S$ ); the English translation will be cited as $K$.

2. A distinct awareness of its place in a tradition is indicated by the $P R$ 's "Preface," throughout; and by $\S \S 3,29,40,57,62,124,140,185,187,206,258,299,356-360$. See also Manfred Riedel, Between Tradition and Revolution, trans. by Walter Wright (Cambridge: Cambridge University Press, 1984), Ch. 7.

3. Hegel's early reflections are most thoroughly considered in the remarkable biography by H. S. Harris, Hegel's Development: Toward the Sunlight 1770-1801 (Oxford: Clarendon, 1972) and Hegel's Development: Night Thoughts (Jena 1801-1806) (Oxford: Clarendon, 1983). See Toward the Sunlight, xviii, 119-153, 231-248, $416 \mathrm{ff}$.

4. $P R$ "Preface," passim. Hegel suggests that there is a rebirth of the sophistic principle that right is based on subjective opinion alone. This view, supported by the 
"positive sciences," by modern religious piety, and by those who think the truth can only be found in that which diverges from what is publicly accepted $(P R, 31,22-23 ; \mathrm{K}, 8,4)$, has led to an open break over the question of the relationship of philosophy to the 'actual world'("Wirklichkeit"), that world in which people are serious about the practice of rights and duties $(P R, 32 ; \mathrm{K}, 9)$.

5. $P R, 31$ note; $\mathrm{K}, 9$ note.

6. A succinct and lucid statement of this view is found in Peter G. Stillman's review of Patrick Riley's Will and Political Legitimacy in The Owl of Minerva, Vol 17, Number 2 (Spring, 1986), 219. Cf. the allusions by Eduard Gans to the hostility aroused in certain quarters by the $P R$, a hostility already growing in the 1830's; in Gans' "Vorwort" to the $P R, 1-3$. See also Ilting's "Introduction" to Vol. I of the Vorlesungen Über Rechtsphilosophie, 23-126; and Karl-Heinz Ilting, "Liberale Demokratie und 'sittlicher' Staat," Archiv für die Geschichte der Philosophie, Band 68, Heft 1 (1986), 2-21.

7. See especially Manfred Riedel, Theorie und Praxis im Denken Hegels (Stuttgart: W. Kohlhammer Verlag, 1965), 76-89.

8. $P R \S 5$.

9. $P R \S \S 6-7,21$. Cf. Joachim Ritter, Hegel and the French Revolution, trans. by Richard Dien Winfield (Cambridge: MIT Press, 1982), 48-49. See also Patrick Riley, Will and Political Legitimacy (Cambridge: Harvard University Press, 1982), whose chapter on Hegel is very useful; Riley's study is oriented toward the "unfolding of the contractarian tradition" and on concepts such as "will, voluntariness, consent and contract"employed in it (vii). As he correctly points out, Hegel's work diverges from this tradition, in particular because he draws "a firm line between will and consent," and then treats will in its generalized form, as the "rational will, or perhaps just reason itself"(164). Cf. also Charles Taylor, Hegel and Modern Society (Cambridge: Cambridge University Press, 1979), 76 ff.; and Hannah Arendt, Willing, Vol. 2 of The Life of the Mind (New York: Harcourt Brace Jovanovich, 1978), 39-51.

10. The argument for the priority of will to both theoretical and practical reason is explicit in the Vorlesungen Über Rechtsphilosphie, ed. Ilting, III, 108-110; IV, 102-109. See K 226-227. See also Charles Taylor, Hegel (Cambridge: Cambridge University Press, 1975), $368 \mathrm{ff}$.

11. See Rousseau's Discours sur l'origine et les fondemens de l'inégalité parmi les hommes, in Oeuvres Completes, ed. Bernard Gagnebin and Marcel Raymond (Paris: 'Bibliothèque de la Pléiade,' Gallimard, 1964), III, 141 ff. Cf. Leo Strauss, Natural Right and History (Chicago: University of Chicago Press, 1953), 265-274; Judith Shklar, Freedom and Independence (Cambridge: Cambridge University Press, 1976), 27; Charles Taylor, Philosophy and the Human Sciences (Cambridge: Cambridge University Press, 1985), 320 ff.; and George Armstrong Kelly, Idealism, Politics and History: Sources of Hegelian Thought (Cambridge: Cambridge University Press, 1976), 341-347. Hegel explicitly differentiates his view of will from that of Rousseau at $P R \S \S 29,258$, in a way that is often characterized as unfair to Rousseau.

12. On the basic steps of willing, considered by themselves, see my "The Meaning of 'Will' in Hegel's Philosophy of Right," Interpretation, 13/2 (May, 1985), 195-212. On the historical situation within which "will" emerges explicitly, see Hegel, The Philosophy of History, trans by J. Sibree (New York: Dover, 1965), 438-447.

13. $P R, 22 ; \mathrm{K}, 3$.

14. $P R \S 2$ says the aim is to look on at the unfolding of the matter itself. See also $\S 31$ Remark. 
15. See $P R \S \S 30-32$; these sections state the organizing principle of the remainder of the work.

16. $P R, 22 ; \mathrm{K}, 3$.

17. $P R \S \S 34-40$; the notion of the person is evidently first approximated, rather inadequately, in Roman law ( $P R \S 40$ Remark) and then deepened with the emergence of biblical religion ( $P R \S \S 357-358)$.

18. $P R$ §§ 2, 31-32. See K. -H. Ilting, "The Dialectic of Civil Society," in Z. A. Pelczynski, ed., The State and Civil Society (Cambridge: Cambridge University Press, 1984), 211-226.

19. $P R \& 32$ Remark; $K, 233$; and $K$ nox's note 73,318 . Cf. the depreciation of 'history' at $P R \S 3$ Remark, $\S 258$ Remark (K p. 156). Cf. also the inclusion of certain kinds of 'historical' views in the category of materialism in G.W.F. Hegel, Lectures on the Philosophy of Religion, 3 vols., ed. by E. B. Speirs (New York: Humanities Press, 1968), I, 51.

20. Riedel, Theorie und Praxis, Ch. 4, especially 83-85.

21. $P R \S 31$ Remark. Note the criticism of Plato at this point, and the related critique of Kant, Rousseau and the French Revolution at $\S 31$ Remark, § 29 Remark, § 258 Remark.

22. This dialectical movement within will and between psychology and its external realizations is an anticipation of what Hegel means on a larger scale by 'history.'

23. $P R \S \S 44-49,57,66,71$.

24. $P R \S \S 121-122,124-126$.

25. $P R \S 185 ; \S 181-188$. Cf. Ritter, Hegel and the French Revolution, 47-52. See also Z. A. Pelczynski, "Freedom in Hegel," in Conceptions of Liberty in Political Philosophy, ed. Z. A. Pelczynski and John Gray (New York: St. Martin's, 1984), 150-181.

26. $P R \S 15$; § 29 Remark; cf. $§ 180$ Remark; § 187; but note also § 206, where Hegel says that in the choice of a profession or occupation, the "individual's arbitrary will [Willkür]" wins its "right, merit and dignity."

27. $P R \S 16-17$.

28. $P R \S 27-29 ; \S 187$.

29. $P R \S 20 ; \S 187$ Remark; K 20. See Hegel, Philosophie des subjektiven Geistes, 3 vols., ed. and trans, M. J. Petry (Dordrecht: D. Reidel, 1979), III, 247-269. Cf. Taylor, Hegel and Modern Society, 79-82, 96; Riley, Will and Political Legitimacy, 164-166. Riley's excellent chapter on Hegel contains also an important critique of his work on both the will and on the state which is said to accommodate it.

30. $P R \S 16 \mathrm{ff}$.

31. On Hegel's critique of irony and extreme subjectivism, see $P R \S 140$ Remark. Cf. Taylor, Hegel and Modern Society, 13-14; and Shklar, Freedom and Independence, 131-132.

32. This is not to deny that public institutions originally come to light as merely inherited and traditional and that they are, even in the best case, a blend of the essential with the accidental or the merely local. Their claim to be vehicles of free will is not self-evident but needs a work of philosophical criticism to be established. Furthermore, the claim can only be established to the extent that the public institutions truly offer a path by which willing in its critical forms can find expression. The challenge to the merely customary and traditional is a part of right; without it, the right implicit in what is established cannot be discerned. Hegel would insist that the 'state' in his sense of the term is that form of human organization in which the free will is both liberated and educated. See PR "Preface," and §§ 184-185, 260-261. 
33. PR §§ 359-360; § 270 Remark (K, 165-168); § 5 Remark. Shklar, Freedom and Independence, 29, 106-110. Cf. Hegel's comments on Plato's supposed idealism in the "Preface" to the PR and at $\S 185$ Remark. Riedel, Between Tradition and Revolution, 188.

34. $P R \S \S 33,341-342$.

35. Hegel gives an important and somewhat independent place to art, the realm of intuition and imagery; to religion, the realm of feeling and representative thinking; and to philosophy, the realm of pure freedom of thought. But world history is the more comprehensive category, "the realization of mind in its whole compass of internality and externality alike." $P R, \S 341$.

36. These are in fact the themes of $P R \S \S 341-360$. Among other points, I would also mention that the doctrine of world history is seen by Hegel as an overcoming of the rupture between individual and society that, from the time of his earliest work, he thought was inherent in biblical religion (which he thought to be the type of utopianism most influential in shaping the foundations of the state rightly understood). That critical separation of world and soul, the city of man and the City of God, is to be overcome in the post-Christian reintegration of mind or spirit into the world which Hegel is here proposing. It is, however, a reintegration which insists on the educative effect of biblical religion, a point which indicates that Hegel is far from considering biblical religion to be only a form of utopianism. Cf. Ritter, Hegel and the French Revolution, pp. 62-68; and H. S. Harris, "And the Darkness Comprehended It Not: The Origin and Significance of Hegel's Concept of Absolute Spirit," in Hegel: L'Esprit Absolu, The Absolute Spirit, ed. Theodore F. Geraets (Ottawa: The University of Ottawa Press, 1984), 15-32.

37. This is the reason why the 'will' as such is no longer an explicit theme in the final section of the $P R$ ( $\$ 341-360)$; in "world history" considered as the highest right, we see, according to Hegel, the idea of right fully displayed and, from this point of view, the two sides of willing are brought together into the more unified whole from which they were only somewhat artificially separated. History is the instance in which willing becomes clear as 'idea,' as something fully intelligible. Cf. Taylor, Hegel and Modern Society, 95-100.

38. Riedel, Theorie und Praxis, 89.

39. The historical realism embedded in historical idealism has also the quality of an exposure of the limits of moral idealism. See PR § 345. Taylor, Hegel, 185-188; $400 \mathrm{ff}$;; 416-421.

40. See $P R \S \S 356-360$ and also, of course, Hegel's Philosophy of History. Cf. Taylor, Hegel, pp. 73-75, where Taylor nicely captures a distinction between the role assigned to will in Hegel's early and late writings.

41. See Judith Shklar, "Hegel's Phenomenology: An Elegy for Hellas," in Z. A. Pelczynski, ed., Hegel's Political Philosophy: Problems and Perspectives (Cambridge: Cambridge University Press, 1971), 73-89 Cf. Franz Rosenzweig, Hegel und der Staat, 2 vols. (Aalen: Scientia Verlag, 1982), I, 40-46.

42. $P R \S 360$.

Donald J. Maletz is Associate Professor of Political Science at the University of Oklahoma. He has published articles on Hegel in several journals. While continuing his work on Hegel, he has also begun a study of Tocqueville's approach to both American constitutionalism and European revolution. 